\title{
PENINGKATAN HASIL BELAJAR MEMBACA PEMAHAMAN MENGGUNAKAN MODEL SQ3R PADA PESERTA DIDIK KELAS IV SD
}

\author{
Sari Selmedani ${ }^{1}$ \\ Universitas Muhammadiyah Sumatera Barat \\ sariselmedani1995@gmail.com \\ Vini Wela Septiana ${ }^{2}$ \\ Universitas Muhammadiyah Sumatera Barat \\ viniwela@gmail.com \\ Yufi Latmini lasari ${ }^{3}$ \\ Institut Agama Islam Negeri Batusangkar \\ yufilatminilasari@iainbatusangkar.ac.id
}

\begin{abstract}
The research originated from the fact that in classs IV SD Negeri 23 Lolong, Padang City, some studets considered readig a learing activity that teded to make them bored and lazy to understand the content of the reading it self, students were less activity because they considere reading less interesting, are more likely to make a scene in class. This type of research is classroom action research using the SQ3R learning model. the research subjects were fourth grade students of SD Negeri 23 Lolong, Padang city with 17 students consisting of 8 boys and 9 girl for 2020/2021 school year. this research was carried out in 2 cycles each cycle consisting of 2 meetings including planning,implementation and reflection. The succes in this research has increased from cycle to cycle. Where the results of RPP cycle I with an average value of $83 \%$ (B), in cycle II with an average value of $86 \%(S B)$, from the aspect of teachers in cycle I with an average value of $86 \%(S B)$, in cycle II with The average value was $94 \%$ (SB), while in the aspect of the first cycle students with an average value of $73 \%(C)$, in the second cycle the average value was $94 \%$ (SB). The learning outcomes in this cycle indicate that an average value of $66 \%(C)$ was obtained, increasing in cycle II with an average value of $83 \%(B)$, thus it can be concluded that the use of the SQ3R learning model can improve student learning outcomes.
\end{abstract}

Keywords: hasi belajar, membaca pemhaman, SQ3R,SD

\begin{abstract}
Abstrak
Penelitian berawal dari kenyataan di kelas IV SD Negeri 23 Lolong Kota Padang dalam pembelajaran sebagian peserta didik menganggap membaca merupakan kegiatan pembelajaran yang cenderung membuat bosan, jenuh dan malas untuk memahami isi bacaan itu sendiri, peserta didik kurang aktif karena menganggap membaca merupakan pembelajaran yang kurang menarik, lebih cenderung membuat keributan didalam kelas. Jenis penelitian adalah penelitian tindakan kelas (PTK) dengan menggunakan model pembelajaran SQ3R. Subjek penelitian adalah peserta didik kelas IV SD Negeri 23 Lolong Kota Padang, dengan jumlah peserta didik 17 orang yang terdiri dari 8 lakilaki dan 9 perempuan tahun ajaran 2020/2021 penelitian ini dilaksanakan 2 siklus setiap siklus terdiri dari 2 kali pertemuan meliputi perencanaan, pelaksanaan dan refleksi. Keberhasilan dalam penelitian ini mengalami peningkatan dari siklus ke siklus. Dimana hasil RPP siklus I dengan ratarata $83 \%$ (B), pada siklus II dengan nilai rata-rata $86 \%$ (SB), dari aspek guru pada siklus I dengan niali rata-rata $86 \%$ (SB), pada siklus II dengan rata-rata nilai $94 \%$ (SB), sedangkan pada aspek peserta didik siklus I dengan rata-rata nilai 73\% (C), pada siklus II dengan rata-rata nilai $94 \%$ (SB). Hasil belajar pada siklus hal ini menunjukkan bahwa diperoleh nilai rata-rata $66 \%(\mathrm{C})$, meningkat pada siklus II dengan nilai rata-rata 83\% (B), dengan demikian dapat disimpulkan penggunaan model pembelajaran SQ3R dapat meningkatkan hasil belajar peserta didik.
\end{abstract}

Kata Kunci: Hasil Belajar, Membaca Pemhaman, SQ3R,S 


\section{PENDAHULUAN}

Pendidikan dasar yang menjadi perhatian pemerintah sejak periode orde baru, sampai saat ini telah mendekati pemerataan. Dengan direncanakan program wajib belajar Sembilan tahun, dimana setiap anak usia sekolah diwajibkan untuk menyelesaikan pendidikan tingkat dasar (Judiani, 2010). Output dari sekolah dasar sangat berpengaruh dalam melaksanakan pendidikan pada jenjang selanjutnya, sehingga sudah tugas pemerintah dan pihak sekolah berupaya menghasilkan sumber daya manusia yang berkualitas.

Bahasa Indonesia sebagai bahasa pengantar pendidikan semua jenjang pendidikan mulai dari pendidikan dasar, menengah hingga pendidikan tinggi memegang peranan penting dalam upaya peningkatan mutu pendidikan, namun dalam kenyataannya pengajaran Bahasa Indonesia di jenjang pendidikan dasar umumnya sekolah dasar dalam hal membaca pemahaman cerita pendek hasilnya masih kurang terbukti dengan kemampuannya. Sebagian besar peserta didik kurang memahami dalam mendengarkan, membaca, menulis dan menceritakan kembali sebuah bacaan (Wahda, 2019).

Dalam proses berbahasa, membaca merupakan keterampilan awal yang harus dimiliki oleh seseorang yang sedang mempelajari bahasa. Namun, kegiatan membaca bukanlah suatu proses yang sederhana karena menyaangkut kegiatan pemahaman isi dari apa yang dibaca sehingga diperlukan pengalaman dan pengetauan yang luas (Apriani, 2009)

Sebagaimana tercantum dalam kurikulum 1994 GBPP. Pendidikan bahasa merupakan sarana belajar komunikasi yang baik dan benar dalam berinteraksi dikehidupan sehari-hari, khususnya di negara ini yang menggunakan Bahasa Indonesia sebagai bahasa resmi. Pengajaran Bahasa Indonesia terdiri dari beberapa aspek kemampuan berbahasa dan bersastra yaitu aspek keterampilan membaca, menulis, menyimak dan berbicara. Empat keterampilan ini saling berkaitan satu sama lain baik dalam kehidupan sehari-hari maupun dalam melakukan proses pembelajaran. Untuk itu, pembelajaran Bahasa Indonesia harus lebih ditingkatkan lagi baik dari segi strategi pembelajaran, fasilitas maupun penunjangnya.

Menurut Apriani (2009) kegiatan membaca memberikan dampak positif khususnya bagi anak sekolah dasar, namun pada umumnya masih sering ditemukan masalah yaitu sulitnya menumbuhkan minat baca pada anak tingkat sekolah dasar. Dari beberapa penelitian menunjukkan bahwa sangat sulit untuk menumbuhkan minat peserta didik dalam memahami sebuah 
bacaan (wacana) yang ditemukan dalam buku bahasa Indonesia.

Cahyorini (2018) mengemukakan bahwa membaca pemahaman adalah kegiatan mengamati tulisan untuk memahami isi bacaan. Membaca pemahaman merupakan proses sungguhsungguh yang dilakukan pembaca untuk memperoleh informasi, pesan, dan makna dalam sebuah bacaan.

Hasil belajar adalah sebagai hasil maksimum yang telah dicapai oleh peserta didik setelah mengalami proses belajar mengajar dalam mempelajari materi pelajaran tertentu. Hasil belajar tidaklah mutlak berupa nilai semata, akan tetapi dapat berupa perubahan atau peningkatan dari sikap, kebiasaan, pengetahuan, penalaran, kedipsiplinan, keterampilan, keuletan, dan nilai sebagainya yang menuju pada perubahan positif.

Septiana (2019) menjelaskan membaca adalah salah satu aspek kemampuan berbahasa yang diajarkan di Sekolah Dasar (SD), dengan tujuan agar peserta didik mengerti maksud yang terkandung dalam bacaan, sehingga memahami isi bacaan dengan baik dan benar.

Pembelajaran membaca pemahaman merupakan proses pembelajaran membaca yang menitik beratkan pada penguasaan teks atau pemahaman teks yang dibaca serta kemampuan peserta didik dalam menjawab beberapa pertanyaan yang diberikan oleh guru ataupun pertanyaan yang muncul pada diri peserta didik setelah membaca wacana teks (Wiradinata, 2017).

Membaca merupakan salah satu kemampuan dasar yang wajib dimiliki oleh setiap individu. Kemampuan membaca menjadi hal yang sangat penting dalam suatu masyarakat sebab melalui membaca dapat diserap berbagai informasi dan wawasan pengetahuan untuk mengembangkan peradaban masyarakat tersebut. Rendahnya kemampuan membaca pemahaman ini menjadi masalah yang serius di tingkat sekolah dasar dan sekolah menengah atas, masih rendahnya tingkat kemampuan membaca pemahaman tersebut, diantaranya dalam hal : memahami ide paragraf, membaca grafik, memahami hubungan antar fakta, hubungan logika, dan menemukan ide bacaan (Asrini \& Tryanasari, 2020)

Membaca pada hakikatnya adalah suatu yang rumit yang melibatkan banyak hal, tidak hanya sekedar melafalkan tulisan, tetapi juga melibatkan aktivitas visual, berpikir, psikolinguistik, dan metakognitif. Sebagai proses visual membaca merupakan proses menerjemahkan simbol tulis (huruf) kedalam kata-kata lisan. Sebagai suatu proses berpikir, membaca mencakup aktivitas pengenalan kata, pemahaman literal, interprestasi, membaca kritis, dan pemahaman kreatif. Pengenalan kata bisa 
berupa aktivitas membaca kata-kata dengan menggunakan kamus (Rahim, 2009).

Keterampilan membaca merupakan salah satu aspek penting dalam berbahasa. Oleh karena itu, peserta didik dituntut untuk menguasai keterampilan membaca, khususnya dalam memahami isi bacaan. Membaca pemahaman merupakan suatu kegiatan yang dilakukan oleh pembaca dengan tujuan untuk memahami isi bacaan atau informasi yang ada dalam teks bacaan. Kemampuan membaca berkaitan erat dengan kemampuan berpikir. Melalui kegiatan membaca peserta didik akan mendapatkan banyak informasi atau pengetahuan yang bermanfaat dalam kehidupan sehari-hari.

Kemampuan membaca pemahaman merupakan kesanggupan pembaca untuk mengerti makna yang terkandung dalam wacana. Tujuan membaca pemahaman adalah untuk memperoleh informasi yang terkandung di dalam tulisan serta dapat dicerna untuk dapat disampaikan kembali baik secara lisan maupun tulisan (Amna et al., 2013).

Dalam gempitan pendidikan karakter, pembelajaran membaca di sekolah harus dilaksanakan dengan berorientasi pada peningkatan kemampuan membaca sekaligus mengambangkan karakter peserta didik. Untuk itu, perlu dilakukan serangkaian upaya menciptakan proses pembelajaran membaca yang bermutu dan berkarakter. Pengembangan pembelajaran membaca dapat dilakukan melalui pemanfaatan tiga saluran penerapan pendidikan karakter, yaitu melalui bahan ajar, model pembelajaran, dan penilaian otentik. Penilaian otentik merupakan saluran yang paling penting sebab penggunaan penilaian otentik akan mencakup pemilihan bahan ajar dan model pembelajaran.

Penilaian otentik memadukan pembelajaran melalui pengreasian berbagai aktivitas belajar yang dilakukan peserta didik selama proses pembelajaran yang di dalamnya terkandung muatan karakter. Penilaian otentik memberikan gambaran nyata kemampuan peserta didik dalam membaca dan memberikan ukuran ketercapaian pengembangan karakter peserta didik, berdasarkan kenyataan tersebut penggunaan pinilaian otentik akan berkontribusi terhadap peningkatan kemampuan membaca pemahaman dan pengembangan karakter peserta didik (Abidin, 2012).

(Rachma, 2019) menjelaskan kegiatan membaca boleh dikatakan tidak dapat terlepas dalam kehidupan sehari-hari. Hal tersebut dikarenakan kegiatan membaca dilakukan setiap hari bahkan setiap saat agar dapat menambah pengetahuan atau informasi bagi pembacanya. Membaca juga merupakan suatu keterampilan berbahasa yang harus 
dimiliki dan dikuasai oleh setiap orang terutama pada peserta didik.

Membaca merupakan salah satu dari empat keterampilan berbahasa yang sangat penting dalam kegiatan pendidikan (Ismawati \& Susandi, 2020). Membaca pemahaman berkaitan dengan permasalahan pada rendahnya keterampilan membaca peserta didik, sehingga metode membaca yang digunakan juga berpengaruh dengan hasil belajar peserta didik. Permasalahan tersebut akan menyebabkan peserta didik mengalami kesulitan dalam memahami isi bacaan, mengajukan pertanyaan yang sesuai dengan bacaan, menentukan ide pokok.

Membaca pemahaman adalah membaca dengan penuh penghayatan untuk menyerap apa yang dikuasai peserta didik/ pembaca. Salah satu sarana sekolah yang mampu menumbuhkan minat baca peserta didik adalah melalui perpustakaan sekolah (Guntari et al., 2017)

Tujuan Membaca hendaknya mempunyai tujuan, karena seseorang yang membaca dengan suatu tujuan, cenderung lebih memahami dibandingkan dengan orang yang tidak mempunyai tujuan. (Rahim, 2009) mengatakan bahwa tujuan membaca mencakup: 1) Kesenangan, 2) Menggunakan strategi tertentu, 3) Mengaitkan informasi baru dengan informasi yang telah diketahuinya, 4) Menampilkan suatu eksperimen atau mengaplikasikan informasi yang diperoleh dari suatu teks dalam beberapa cara lain dan mempelajari tentang struktur teks, 5) Menjawab pertanyaan-pertanyaan yang spesifik.

Rahim (2009) mengemukakan bahwa kemampuan membaca merupakan sesuatu yang vital dalam suatu masyarakat terpelajar. Namun, anak-anak yang tidak memahami pentingnya belajar membaca tidak akan termotivasi untuk belajar. Belajar membaca merupaka usaha yang terus menerus, dan anak-anak yang melihat tingginya nilai (value) membaca.

Membaca sekilas bertujuan untuk memperoleh kesan umum dari sebuah buku. Akan tetapi, buku itu juga harus dipelajari secara intensif. Kita tidak hanya membaca buku itu secara meluas, tetapi perlu juga secara mendalam. Membaca secara intensif diperlukan untuk memperoleh informasi yang lebih bermutu, lebih berbobot, lebih kental dan lebih utuh. Untuk kegiatan membaca seperti itu, kita dituntut untuk relational thinking (Sulistyaningsih, 2008).

Keterampilan adalah sebuah usaha untuk mengetahui dan memperoleh ilmu pengetahuan. Membaca adalah salah satu dari empat kemampuan berbahasa pokok dan merupakan suatu bagian atau komponen dari komunikasi tulisan. Dalam komunikasi tulisan lambang-lambang bunyi diubah menjadi lambang-lambang bunyi dibuah menjadi lambang-lambang tulisan atau huruf. Membaca adalah aktivitas yang komplek dengan menggerakkan sejumlah tindakan 
yang terpisah-pisah menurut (Wahyuningsih et al., 2019).

Proses membaca terlibat dalam berbagai faktor : 1) faktor internal dapat berupa intelegensi (IQ), minat, sikap, bakat, motivasi, tujuan membaca dan sebaginya. 2) faktor eksternal bisa dalam bentuk sarana membaca, teks bacaan (sederhana-berat, mudah-sulit), faktor lingkungan atau faktor latar belakang sosial ekonomi, kebiasaan, dan tradisi membaca (Ilmi et al., 2018).

Membaca pemahaman merupakan bagian dari jenis kegiatan membaca dalam hati yang hanya mengandalkan kemampuan visual, pemahaman, serta ingatan dalam menghadapi bacaan, tanpa mengeluarkan suara atau menggerakkan bibir dengan tujuan belajar serta memperoleh wawasan yang lebih tinggi. Membaca intensif atau pemahaman adalah membaca dengan penuh penghayatan untuk menyerap apa yang seharusnya dikuasai peserta didik/ pembaca (Saddhono \& Slamet, 2014).

Salah satu hambatan yang dihadapi peserta didik berkesulitan belajar yaitu rendahnya tingkat pemahaman terhadao suatu bacaan. (Afrianti \& Marlina, 2021). Sedangkan salah satu kemampuan yang harus dimiliki peserta didik adalah kemampuan membaca pemahaman, dengan tujuan agar peserta didik memahami isi teks bacaan yang telah dibacanya (Zuhari et al., 2018).

Prinsip-prinsip membaca yang didasarkan pada penelitian yang paling mempengaruhi pemahaman membaca ialah seperti yang dikemukakan oleh (McLaughlin \& Allen, 2002) yaitu :

Pemahaman merupakan proses kontruktivis sosial, guru membaca yang profesional (unggul) mempengaruhi belajar siswa, siswa menemukan manfaat membaca yang berasal dari berbagai teks pada berbagai tingkat kelas, perkembangan kosakata dan pembelajaran mempengaruhi pemahaman membaca, strategi dan keterampilan membaca bisa diajarkan, asesmen yang dinamis menginformasikan pembelajaran membaca pemahaman.

Robinson (1946) mengembangkan model SQ3R yaitu model pembelajaran yang efektif dalam membantu seseorang untuk memahami dan menguasai materi pembelajaran yang sedang dipelajari/ dibaca. Pada proses pembelajaran, ada beberapa peserta didik yang mengalami kesulitan dalam memahami suatu bacaan, bahkan tidak jarang agar dapat memahami suatu bacaan tersebut peserta didik membaca lebih dari satu kali.

Pembelajaran ini adalah strategi membaca yang dapat mengembangkan meta kognitif peserta didik, yaitu dengan menugaskan peseta didik untuk membaca bahan belajar secara seksama dan cermat, degan sintak : survei dengan mencermati teks bacaan dan mencatat, menandai kata kunci, quetation dengan membuat pertanyaan (mengapa, bagaimana, dan darimana), read dengan membaca teks dan cari jawabannya, recite dengan pertimbangkan jawaban yang 
diberikan, dan review dengan cara meninjau ulang menyeluruh (Ngalimun, 2017).

Karakteristik model SQ3R menurut Syah (1995) yaitu : a) Peserta didik berperan aktif dalam pembelajaran, b) Guru sebagai fasilitator dan monitor aktif, c) Pembelajaran dibentuk dalam kelompok-kelompok kecil dan guru sebagai pembimbing, d) Peserta Didik dihadapkan pada suatu fenomena dan kemudian diminta untuk mensurvey terlebih dahulu.

Model SQ3R memberikan gambaran umum tentang bahan yang dipelajari, peserta didik mampu menemukan pertanyaan dari judul/subjudul bab. Peserta didik membaca secara aktif untuk mencari jawaban dari pertanyaan, kemudian menceritakan jawabanjawaban dari pertanyaan yang telah tersusun tanpa menggunakan buku untuk melatih daya ingatnya dan dilakukan peninjauan ulang atas seluruh pertanyaan dan jawaban. Sehingga diperoleh sebuah simpulan yang singkat, tetapi dapat menggambarkan seluruh jawaban atas pertanyaan yang telah diajukan.

Menurut Ilmi et al. (2018) kelebihan model SQ3R adalah : a) Lebih memberikan pemahaman yang luas tentang materi pelajaran yang terdapat didalam buku teks tersebut, b) Membuat siswa menjadi lebih aktif, c) Membuat terarah langsung pada inti sari atau kandungan-kandungan pokok materi yang tersirat dan tersurat dalam teks. Sehingga tidak menutup kemungkinan mencapai proses pembelajaran yang efektif sesuai tujuan yang diharapkan. Adapun kelemahan model SQ3R adalah tidak semua jenis bacaan dapat dipelajari dengan metode ini.

SQ3R merupakan suatu teknik untuk memahami bacaan dengan melalui lima langkah kegiatan, yaitu : menelusuri, bertanya, baca, mengutarakan dan mengulang kembali suatu bacaan agar mudah diingat (Sulistyaningsih et al., 2014). Beragam metode membaca yang dirumuskan untuk memahami wacana teks dengan hasil pemahaman optimal, salah satunya adalah metode membaca SQ3R. Metode membaca ini menaawarkan cara membaca dengan cara meneliti seluruh isi teks (survei), menyusun pertanyaan yang bersumber dari teks (question), membaca teks secara aktif (read), memahami jawaban yang telah ditemukan (recite), dan meninjau ulang seluruh jawaban (review) (Wiradinata, 2017).

Langkah-langkah SQ3R sebagai berikut a) Survei atau prabaca merupakan cara untuk mengenal bahan bacaan sebelum membacanya secara lengkap. Kegiatan prabaca dilakukan untuk mengenal organisasi dan ikhtisar umum dari suatu bacaan. Dalam kegiatan survei ini dapat dilihat judul, subjudul, paragraf, dan lain sebagainya (Ngalimun, 2017). b) Tahapan question yaitu membantu daftar pertanyaan sebanyakbanyaknya tentang isi bacaan. Tahapan ini dapat dilakukan dengan mengubah judul dan subjudul menjadi kalimat pertanyaan. Kalimat tanya dapat menggunakan kata tanya siapa, apa, kapan, dimana, mengapa dan 
bagaimana (Ngalimun, 2017). c) Setelah melakukan survei dan mengajukan pertanyaan, tahapan selanjutnya adalah membaca secara keseluruhan bahan bacaan Membaca merupakan tahapan ketiga, bukan tahapan pertama atau satu-satunya tahapan untuk menguasai bacaan (Wahyuningsih et al., 2019). d) Tahapan keempat adalah recite, tahapan ini dilakukan untuk menjawab pertanyaan yang telah dibuat, menyebutkan hal-hal penting dari bacaan dan dapat juga membuat catatan seperlunya (Ngalimun, 2017). e) Tahapan ini digunakan untuk mengulang dan menelusuri kembali bagianbagian penting dari bacaan, menemukan pokok-pokok penting yang perlu diingat kembali. Tahap ini selain membantu daya ingat dan memperjelas pemahaman juga untuk mendapatkan hal-hal penting yang terlewatkan (Ngalimun, 2017). Menurut Sudjana (2014) penilaian hasil proses belajar mengajar harus memenuhi hal-hal sebagai berikut: 1) Ranah kognitif - pengetahuan, 2) Ranah afektif - sikap peserta didik.

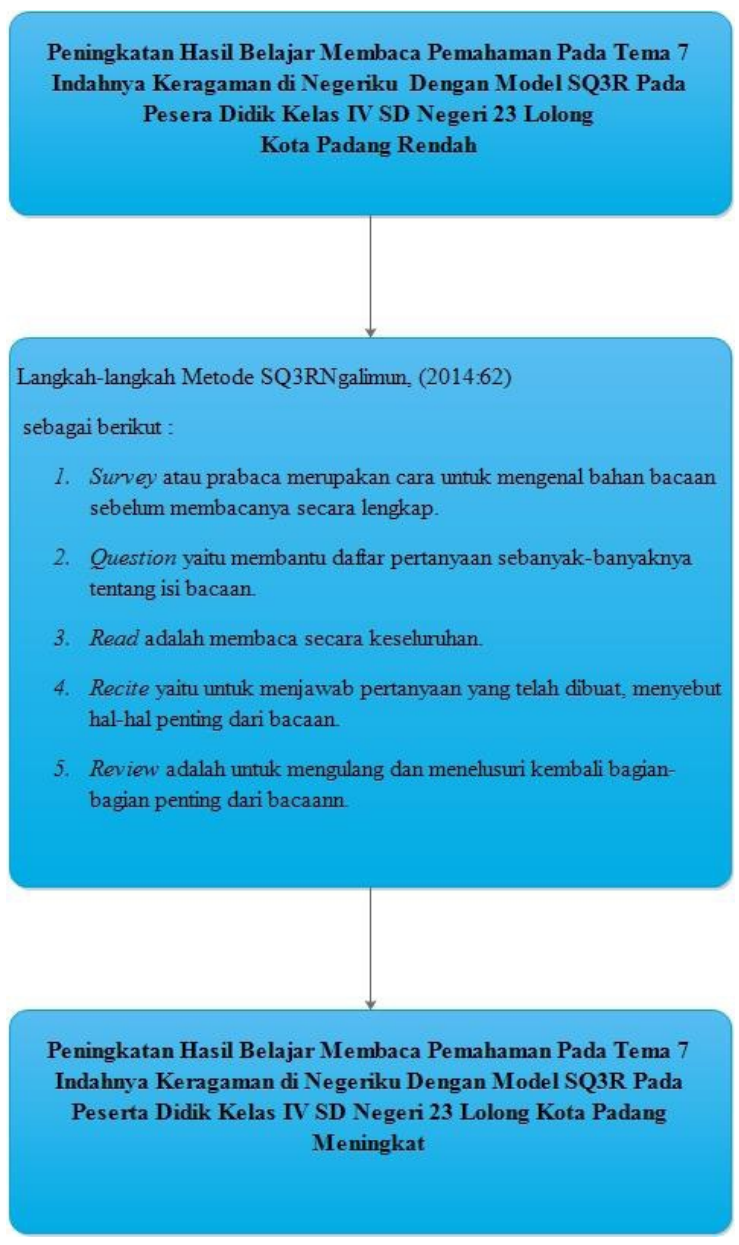

\section{METODE PENELITIAN}

Tempat penelitian Penelitian telah dilaksanakan pada kelas IV SD Negeri 23 Lolong Kota Padang. Subjek penelitian Peserta didik kelas IV SD Negeri 23 Lolong Kota Padang. Waktu penelitian Penelitian telah dilakukan pada semester 2 (genap) pada siklus I pertemuan I dilaksanakan pada tanggal 28 Januari 2021, dan pada siklus I pertemuan II dilaksanakan pada tanggal 30 Januari 2021 dan pada siklus II pertemuan I dilaksanakan pada tanggal 1 Februari 2021 serta siklus II pertemuan II dilaksanakan pada tanggal 2 Februari 2021 tahun ajaran 2020/2021. 
Penelitian yang telah dilakukan bertujuan untuk memperbaiki proses pembelajaran dan meningkatkan hasil belajar peserta didik pada pembelajaran membaca pemahaman di kelas IV SD Negeri 23 Lolong Kota Padang, dengan menggunakan model pembelajaran SQ3R.

Penelitian ini difokuskan pada perencanaan, pelaksanaan, dan penilaian proses dengan pendekatan kuantitatif dan kualitatif. Penelitian ini diawali dengan menggunakan penelitian pendahuluan (pra penelitian tindakan kelas). Selanjutnya dengan mengambil pola sebuah siklus maka penelitian ini terdiri dari empat tahap yaitu perencanaan, pelaksanaan, pengamatan, dan refleksi. Metode pengumpulan data melalui Teknik tes. Tes merupakan alat atau prosedur yang digunakan untuk mengetahui atau mengukur sesuatu dalam suasana, dengan cara dan aturan-aturan yang sudah ditentukan.

Teknik non tes melalui observasi digunakan untuk mengumpulkan data tentang aktivitas peserta didik dalam proses belajar mengajar. Implementasi pembelajaran SQ3R berlangsung. Catatan lapangan (field notes) adalah catatan yang dibuat oleh peneliti atau mitra peneliti yang melakukan pengamatan terhadap subjek atau observasi atau objek penelitian tindakan kelas.

Analisis data dan interprestasi hasil analisis Setelah data terkumpul yang terdiri dari hasil observasi terhadap aktivitas peserta didik dan aktivitas pendidik dalam melaksanakan pembelajaran dengan menggunakan model SQ3R serta hasil belajar yang berupa hasil nilai tes setiap akhir siklus.

Penelitia ini dilaksanakan pada tanggal 30 Januari 2021 dan pada siklus II pertemuan I dilaksanakan pada tanggal 1 Februari 2021 serta siklus II pertemuan II dilaksanakan pada tanggal 2 Februari 2021 tahun ajaran 2020/2021.

\section{HASIL DAN PEMBAHASAN}

Penelitian dilaksanakan di kelas IV SD Negeri 23 Lolong Kota Padang pada tema 7 Indahnya Keragaman di Negeriku tahun ajaran 2020/2021. Pelaksanaan tindakan dilaksanakan dalam dua siklus dengan rentang waktu dua minggu. Dalam pelaksanaan tindakan peneliti bertindak sebagai guru sedangkan guru kelas IV dan teman sejawat sebagai observer. Pelaksanaan tindakan terbagi atas II siklus, dimana data setiap siklus dipaparkan secara terpisah dari siklus yang lainnya agar terlihat persamaan, perbedaan, perubahan atau perkembangan dari alur siklus tersebut. Hasil penelitian pada setiap siklus tersebut dideskripsikan sebagai berikut.

Siklus I tahap perencanaan kegiatan pembelajaran dituangkan dalam suatu rancangan pelasanaan pembelajaran (RPP). Rencana pelaksanaan pembelajaran merupakan bentuk operasional dari 
kegiatan pembelajaran yang dilaksanakan dalam teks. RPP memberikan gambargambaran tentang bentuk kegiatan yang akan dilaksanakan.

Kegiatan pembelajaran dilaksanakan dengan periode dua kali dalam seminggu selama satu bulan, dilaksanakan sesuai dengan rancangan pelaksanaan pembelajaran yang telah disusun. Kegiatan pembelajaran dilaksanakan selama dua siklus. Dimana siklus I dibagi dalam dua kali pertemuan, dan ada siklus II dibagi dua kali pertemuan juga. Dengan langkahlangkah model pembelajaran SQ3R : a. (Peserta didik melakukan survei terhadap teks bacaan), b. (Peserta didik mengajukan pertanyaan (question), c. (Peserta didik membaca teks bacaan secara keseluruhan (read), d. (Peserta didik berdiskusi dengan teman sebangku dan menjawab pertanyaan (recite) mengenai informasi baru yang terdapat pada teks bacaan), e. (Peserta didik mengulang (review) hasil diskusi kelompoknya dalam bentuk laporan hasil diskusi).

Pengamatan pembelajaran dilakukan secara berkelanjutan mulai dari tindakan awal sampai siklus I dan II. Tindakan akhir dari pengamatan ini direfleksikan untuk perencanaan pada pertemuan selanjutnya.

Hasil belajar dinilai dari tiga aspek yaitu ranah kognitif, afektif dan psikomotor. Penilaian pada aspek kognitif dinilai pada kegiatan individu dan tes yang dilakukan di akhir kegiatan pembelajarn. Hasil ini merupakan penentu apakah kegiatan pembelajaran yang dilaksanakan berhasil atau tidak.

\section{KESIMPULAN}

Berdasarkan hasil penelitian dan pembahasan, peneliti dapat menyimpulkan sebagai berikut :

Rencana pelaksanaan pembelajaran dengan menggunakan model SQ3R dibagi dalam tiga tahap pembelajaran yaitu kegiatan awal, inti dan akhir. Pada kegiatan awal, dilaksanakan kegiatan pengaktifan pengetahuan peserta didik. Pada tahap inti, dilaksanakan pembelajaran dengan menggunakan langkah-langkah model SQ3R, serta tahap akhir dilaksanakan penyimpulan pembelajaran dan pemberian evaluasi.

Bentuk pelaksanaan pembelajaran Bahasa Indonesia disesuaikan dengan langkah-langkah penggunaan model SQ3R yaitu peserta didik melakukan survei terhadap teks bacaan. Setiap orang mengajukan pertanyaan (question). Setiap orang membaca teks secara keseluruhan (read). Setiap orang menjawab pertanyaan yang telah diajukan (recite). Setiap orang mengulang hasil diskusinya (review). Pada kegiatan akhir yaitu dilakukan tindak lanjut dan evaluasi sesuai dengan materi yang telah dibahas dalam pembelajaran.

Hasil penelitian menunjukkan bahwa ada peningkatan hasil belajar. Dilihat dari 
pengamatan RPP siklus I pertemuan I adalah 83\% (B), siklus II pertemuan II adalah $88 \%$ (SB). Hasil pengamatan dari aspek guru siklus I pertemuan I adalah $88 \%$ (SB), aspek guru siklus I pertemuan II adalah 92\% (SB), aspek guru siklus II pertemuan I adalah 92\% (SB), aspek guru siklus II pertemuan II adalah 96\% (SB). Sementara dari aspek peseta didik siklus I pertemuan I adalah $67 \%(\mathrm{C})$, aspek peserta didik siklus I pertemuan II adalah 79\% (B), aspek peserta didik siklus II pertemuan I adalah 92\% (SB), aspek peserta didik siklus II pertemuan II adalah 96\% (SB)

Hasil peserta didik dalam pembelajaran Bahasa Indonesia dengan menggunakan model SQ3R di kelas IV SD Negeri 23 Lolong Kota Padang sudah meningkat. Hasil penelitian yang telah dilakukan pada siklus I dan siklus II diperoleh peningkatan. keberhasilan pada aspek kognitif, afektif, dan psikomotor peserta didik. Pada siklus I rata-rata aspek kognitifnya $66 \%$ (C) pada siklus II meningkat menjadi $85,58 \%$ dan rata-rata afektif pada siklus I adalah 77\% (B) dan pada siklus II meningkat menjadi 81\% (B) dan rata-rata pada aspek psikomotor pada siklus I adalah 75\% (B) dan pada siklus II meningkat menjadi $82 \%$ (B), dilihat ratarata ketiga aspek tersebut pada siklus I adalah $73 \%$ (B), dan pada siklus II meningkat menjadi $82 \%$ (B).

\section{REFERENSI}

Abidin, Y. (2012). Model Penilaian Otentik Dalam Pembelajaran Membaca Pemahaman Beroreintasi Pendidikan KarakteR. Jurnal Pendidikan Karakter, O(2), Article 2. https://doi.org/10.21831/jpk.v0i2.13 01

Afrianti, M. N., \& Marlina, M. (2021). Peningkatan Kemampuan Membaca Pemahaman Melalui Strategi Probing-Prompting bagi Anak Berkesulitan Belajar. Jurnal Basicedu, 5(1), 272-279.

Amna, P., Azwandi, Y., \& Yunus, M. (2013). Meningkatkan Kemampuan Membaca Pemahaman Pada Siswa Tunarungu Dengan Menggunakan Teknik Skimmin G. 2, 9.

Apriani, R. (2009). Penerapan Metode Sq3r (Survey-Question-Read-Recite-

Review) Dalam Pembelajaran Membaca Pemahaman Teks Bahasa Jepang (Dokkai).

Asrini, S., \& Tryanasari, D. (2020). Implementasi pembelajaran membaca pemahaman dengan menggunakan metode sq3r. Prosiding Konferensi Ilmiah Dasar, 2, 383-387.

Cahyorini, B. W. (2018). Pengaruh Strategi Pembelajaran sq3r (Survey, Question, Read, Recite, Review) Terhadap Pencapaian Hasil Belajar Membaca Pemahaman Siswa Kelas Iv Sdn Kebonsari 04 Jember.

Guntari, G., Bukhari, B., \& Habibah, S. (2017). Kontribusi Perpustakaan Sekolah terhadap Kemampuan Membaca Pemahaman Siswa Kelas $V$ SD Negeri 5 Banda Aceh (Issue 1) [Journal:eArticle, Universitas Syiah Kuala].

https://www.neliti.com/id/publicatio $\mathrm{ns} / 187992 /$

Ilmi, D. N., Hermawan, R., \& Riyadi, A. R. (2018). Metode Pembelajaran SQ3R 
untuk Meningkatkan Kemampuan Membaca Pemahaman. Jurnal Pendidikan Guru Sekolah Dasar, 2(4), 88-99.

Ismawati, K., \& Susandi, S. (2020). Implementasi Metode SQ3R pada Teks Eksposisi sebagai Upaya Peningkatan Keterampilan Membaca Pemahaman Siswa. Prosiding Seminar Nasional IKIP Budi Utomo, 1(01), 650-657. https://doi.org/10.33503/prosiding.v $1 \mathrm{i} 01.1007$

Judiani, S. (2010). Implementasi pendidikan karakter di sekolah dasar melalui penguatan pelaksanaan kurikulum. Jurnal Pendidikan Dan Kebudayaan, 16(9), 280-289.

McLaughlin, M., \& Allen, M. B. (2002). Guided Comprehension: A Teaching Model for Grades 3-8. ERIC.

Ngalimun. (2017). Strategi Pembelajaran. Parama Ilmu.

Rachma, T. N. (2019). Keefektifan Pembelajaran Membaca Pemahaman Teks Negosiasi Menggunakan Metode Sq3r Dan Pqrst Pada Siswa Kelas X Sma Negeri 12 Semarang [PhD Thesis]. Universitas Negeri Semarang.

Rahim, F. (2009). Pembelajaran Membaca Sekolah Dasar. Jakarta: Bumi Aksara.

Robinson, F. P. (1946). Are" nondirective" techniques sometimes too directive? Journal of Clinical Psychology.

Saddhono, K., \& Slamet, Y. (2014). Pembelajaran keterampilan berbahasa Indonesia: Teori dan aplikasi. Graha Ilmu.

Septiana, V. W. (2019). Peningkatan Aktivitas dan Hasil Belajar Membaca Pemahaman Dengan Model Pembelajaran Kooperatif Tipe Cooperative Integrated
Reading and Composition (CIRC) di Kelas V SD. 1(01).

Sudjana, N. (2014). Penilaian hasil proses belajar mengajar.

Sulistyaningsih, L. S. (2008). Metode SQ3R. Diperoleh.

Sulistyaningsih, L. S., Laksono, K., Mintowati, M., \& Pratiwi, Y. (2014). Membaca 2 .

Syah, M. (1995). Psikologi pendidikan suatu pendekatan baru. Bandung: Remaja Rosdakarya.

Wahda, W. (2019). Pengaruh Penerapan Metode Bermain Peran Dalam Pelajaran Bahasa Indonesia Terhadap Kemampuanbekerja Sama Siswa Di Sdn 112 Belajen Kabupaten Enrekang. Eklektika: Jurnal Pemikiran Dan Penelitian Administrasi Pendidikan, 6(1), 6371.

Wahyuningsih, B. Y., Wardiningsih, R., \& Sugianto, R. (2019). Peningkatan Keterampilan Membaca Pemahaman Mahasiswa melalui Pendekatan Metode SQ3R dan PQRST. PENSA, 1(1), 153-160.

Wiradinata, R. (2017a). Keefektifan Metode SQ3R Berbasis Teks Bernilai Budaya Dalam Pembelajaran Membaca Pemahaman. Jurnal Tuturan, 4(1), 722-737.

Wiradinata, R. (2017b). Keefektifan Metode SQ3R Berbasis Teks Bernilai Budaya Dalam Pembelajaran Membaca Pemahaman. Jurnal Tuturan, 4(1), $722-737$.

Zuhari, A. E., Djumhana, N., \& Mulyasari, E. (2018). Penerapan Metode Guide Reading Untuk Meningkatkan Kemampuan Membaca Pemahaman Siswa IV SD. Jurnal Pendidikan Guru Sekolah Dasar, 3(2), 11-21. 